\title{
PERFORMANCE, CARCASS AND INTERNAL ORGANS CHARACTERIZES OF BROILER CHICKENS WITH PHYTASE SUPPLEMENTATION FROM Burkholderia sp. Strain HF.7
}

\author{
HAFSAN ${ }^{1 \times 凶}$, Aminah HAJAH THAHA ${ }^{2}$, Asmuddin NATSIR ${ }^{3}$ and Ahyar AHMAD 4 \\ 1Biology Department, Faculty of Science and Technology, Universitas Islam Negeri Alauddin, Sultan Alauddin Street, Gowa 92118, Indonesia \\ 2Animal Science Department, Faculty of Science and Technology, Universitas Islam Negeri Alauddin, Sultan Alauddin Street, Gowa 92118, Indonesia \\ ${ }^{3}$ Department of Nutrition and Animal Feed, Faculty of Animal Sciences, Hasanuddin University, Perintis Kemerdekaan Street Km. 10 Tamalanrea, Makassar 90245 , \\ Indonesia \\ ${ }^{4}$ Chemistry Department, Mathematics and Natural Science Faculty, Hasanuddin University, Perintis Kemerdekaan Street Km. 10 Tama lanrea, Makassar 90245 , \\ Indonesia \\ Email: hafsan.bio@uin-alauddin.ac.id; (D) ORCiD: 0000-0001-5821-0164 \\ Supporting Information
}

ABSTRACT: Feed formulation with phytase supplementation is an innovation in the feed industry to improve monogastric feed quality without increasing production costs. This study aims to determine the carcass weight of broilers and the percentage of internal organs by providing various feeds, including those supplemented with phytase in phytase units (FTU) from Burkholderia sp. strain HF.7. A completely randomized experimental design was used in this study, using 108 broilers for five weeks of maintenance in three treatments with six replicas, each replica consisting of six broilers. The experimental feed given to broilers was basal feed without phytase supplementation (P1), basal feed +750 FTU phytase (P2) and commercial feed (P3), each with the category of starter phase and finisher phase. Carcass weight and percentage of organs in broilers (liver, heart, gizzard, and lymph) were measured in each treatment unit. The results showed that broilers that consumed phytase supplemented feed had a higher carcass weight with a lower feed conversion value than broilers fed basal feed without phytase. These findings also indicate that the addition of phytase from Burkholderia sp. HF.7 strain at $750 \mathrm{FTU} / \mathrm{kg}$ feeds does not interfere with the organs of broilers' physiological function because of no increase in the percentage of the liver, heart, gizzard, and lymph.

Keywords: Broiler, Burkholderia, Internal organs, Performance, Phytase.

\section{INTRODUCTION}

Broiler farming is a prospective productive farming and the increase of nutrient conscious and public consumption of food animal-based (Walker et al., 2005; Manning et al., 2006; Bonham et al., 2006). This opportunity encourages (Benton and Bailey, 2019). One of the essential and economic aspects of broiler maintenance is feed (Tallentire et al., 2016). The content and availability of nutrients determine feed quality to meet broilers' needs during the maintenance period (Wenk, 2000; Abdollahi et al., 2013). Various feed formulations have been arranged in such a way to achieve maximum productivity (Daghir, 2009; Santoso, 2012; Krishnasamy et al., 2015). This effort, feed cost is one of the main obstacles of broiler production. Recently, various efforts have made in order to find ways to reduce feed costs.

One effort that can accomplish in order to improve the feed quality while reducing the production cost is adding feed additive which is a material or combination of ingredients (Tallentire et al., 2016). The supplementation of phytase is efforts that can be an option in innovative feed formulation to improve the nutritional value of broiler feed through improving nutrient utilization; increase utilization of phosphorus and calcium in the feed (Augspurger et al., 2003; Aureli et al., 2011; Hafsan et al., 2017), amino acid absorption (Cowieson et al., 2004) and the ability to digest feed ingredients (Rutherfurd et al., 2012). Increase utilization of nutrients by phytase in performing the phosphate group release function of the Mio-inositol ring on phytate compounds which the main form of phosphorus storage in broiler is feed ingredients. The phosphate group's release implies the release of other essential proteins and minerals bound to the phytate complex, hence its availability in the feed has a unique effect (Hirvonen et al., 2019).

The usage of phytase with high stability to temperature and $\mathrm{pH}$ at specific dosage has reported significantly improved broiler performance as it improved nutrient digestibility in the feed (Shirley and Edwards, 2003; Hafsan et al., 2018; Cowieson et al., 2006). Extra-phosphorus effects as well as the release of amino acids, and cations bound such as calcium, magnesium and iron lead to absorbed nutrients increased in metabolic and biosynthetic processes, affected of higher energy retention leading to increased broiler performance (Cowieson et al., 2006; Selle et al., 2000). Indicators of broiler metabolic processes reflected in a good performance as well as lead to excellent carcass properties and a balanced percentage of internal organs (Angel et al., 2006; Çimrin and Demirel, 2008) as a result of increased availability of phosphate, higher nitrogen retention and increased solubility of phytate complexes in the digestive tract of broilers 
(Shirley and Edwards, 2003). The maximum utilization of nutrients such as protein, phosphorus, and calcium by broilers is the increased performance indicated by weight gain at harvest. Besides, feed conversion value will decrease due to the maximum absorption of nutrients (Humer et al., 2015; Savita et al., 2017; Maas et al., 2021). Anti-nutritional substances, including phytic acid, will cause the digestive organs to work longer to cause physiological disorders, including the digestive organs' weight. Therefore, this study reveals the effect of phytase giving by Burkholderia sp. Strain HF.7 (Hafsan et al., 2018) on the profile of broilers' internal organs.

\section{MATERIALS AND METHODS}

This study was an experimental study using complete randomized design, namely three treatments with six replications. The variables observed in this study were the appearance of broiler production, which included carcass weight and percentage of internal organs (liver, heart, gizzard, and lymph). Day Old Chick (DOC) broiler Cobb strain used without separating males and females (unsexed). Maintenance performed for five weeks. The cage used roofed with a litter system with dimensions is $250 \times 250 \times 80 \mathrm{~cm}$, which is equipped with lighting and functions to warm the cage. Ten broilers occupied each plot. The cage equipment used was two feedings vessel of $500 \mathrm{~g}$ and drinking water containers of $500 \mathrm{~mL}$ capacity. Measurement of the temperature and humidity of the cage environment using a thermometer and thermo hygrometer. The average temperature of the cage was $27.69^{\circ} \mathrm{C}$, and the average humidity was $75.88 \%$. Feed and drinking water were given in ad libitum every morning, afternoon and evening based on treatment. Phytase powder from Burkholderia sp. strain HF.7 was added to every $5 \mathrm{~kg}$ of feed a homogenized before fed the broiler. Treatment feed was given based on the maintenance period, namely starter and finisher.

Feed experiments using three types of feed. The basal feed used in this study was obtained from conventional feed mills. The ingredients of the basal feed composition are yellow corn, rice bran, soybean meal, Meat and Bone Meal, coconut oil, $\mathrm{CaCO3}$, dicalcium phosphate, DL-methionine, L-Lysine, premix. A basal feed with the composition is used as P1 feed and basal feed supplemented with 750 FTU of Burkholderia strain HF.7 as P2. A comparison feed (P3) shows that commercial feed is obtained from one Poultry shop in Makassar, without knowing its ingredients. The chemical composition of the fodder with its nutritional content is presented in Table 1.

Table 1 - Composition and nutrient of broiler feed ingredients.

\begin{tabular}{|c|c|c|c|c|c|c|}
\hline \multirow{2}{*}{ Feed Composition } & \multicolumn{3}{|c|}{ Starter (\%) } & \multicolumn{3}{|c|}{ Finisher (\%) } \\
\hline & P1 & P2 & P3 & P1 & P2 & P3 \\
\hline Corn & 53 & 53 & - & 60 & 60 & - \\
\hline Rice bran & 6 & 6 & - & 5 & 7 & - \\
\hline Soybean meal & 28 & 28 & - & 21.2 & 19.2 & - \\
\hline Meat and bone meal & 8 & 8 & - & 8.3 & 8.3 & - \\
\hline Coco oil & 3 & 3 & - & 3.3 & 3.3 & - \\
\hline $\mathrm{CaCO} 3$ & 0.8 & 0.8 & - & 1 & 1 & - \\
\hline Dicalcium phosphate & 0.1 & 0.1 & - & 0 & 0 & - \\
\hline DL-methionine & 0 & 0 & - & 0.2 & 0.2 & - \\
\hline L-lysine & 0.3 & 0.3 & - & 0.5 & 0.5 & - \\
\hline Premix & 0.5 & 0.5 & - & 0.3 & 0.3 & - \\
\hline Total (\%) & 100 & 100 & 100 & 100 & 100 & 100 \\
\hline \multicolumn{7}{|l|}{ Chemical composition } \\
\hline Phytase (FTU/kg) & 0 & 750 & 0 & 0 & 750 & 0 \\
\hline Crude Protein & 22.75 & 22.75 & 22.80 & 20.11 & 0.80 & 22.40 \\
\hline Raw fat & 3.60 & 3.60 & 3.85 & 3.30 & 0.30 & 3.45 \\
\hline Phosphorus & 0.79 & 0.79 & 0.37 & 0.71 & 0.45 & 0.60 \\
\hline Calcium & 1.43 & 1.43 & 1.03 & 1.43 & 1.03 & 1.20 \\
\hline Phytate & 0.33 & 0.33 & 0.20 & 0.29 & $0 . .29$ & 0.26 \\
\hline Metabolic energy (KI/kg) & 3.03 & 3.03 & 3.05 & 3.14 & 3.14 & 3.16 \\
\hline
\end{tabular}

\section{Ethical approval}

This research was conducted in accordance with the recommendations of research ethics approval using animal subject by Health Research Ethics Committee of Universitas Islam Negeri Alauddin Makassar, referred to Legislation of the Republic of Indonesia No. 18, 2009.

\section{Statistical analysis}

The gathered data is analyzed with analyzed with ANOVA of Complete Randomized Design. Estimated conversion of feed consumed by broilers is determined by calculating the ratio between the amount of feed consumed and the resulting weight gain. Bodyweight gain was calculated from the chicken's weight last week minus the initial bodyweight of the chicken. Percentage determination of internal organ was obtained from dividing internal organ weight by broiler's live weight in $100 \%$ after fat dismissing. 


\section{RESULTS AND DISCUSSION}

As a parameter to determine feed quality, the feed conversion value of each type of feed treated was determined beforehand by compared between the amount of feed consumed with broiler body weight gain during maintenance has ended. Feed conversion value indicates the level of feed efficiency, meaning the lower the value of feed conversion, the higher the feed efficiency and more economical. Figure 1 shows that the average value of feed conversion produced in this study was 1.922 - 2.591.

Variance analysis has shown very significant differences between treatments $(P<0.01)$. The basal feed which was not added phytase (P1) was indicated to produce a significantly high feed conversion compared to other treatments. P2 feed given to broiler shows the lowest feed conversion value and relatively similar (not significantly different) to P3. This disparity indicates that the best feed conversion obtained in P2 with the addition of 750 FTU of Burkholderia sp. strain HF.7. However, statistically, there is no significant difference from the commercial feed, which has been used extensively by farmers. The lowest feed conversion rate among these treatments (1.922) has provided an optimal description of this broiler's digestive system in converting $1.922 \mathrm{~kg}$ of feed into $1 \mathrm{~kg}$ of the carcass. According to (Dos Santos et al., 2013; Liu et al., 2014), the lower feed conversion rates indicate that broilers are better at converting feed into meat and feed can be said to be of good quality. This study has proven to indicate that the lowest feed conversion rate by giving 750 FTU/kg phytase from Burkholderia sp. strain HF.7 has improved broiler metabolism. Feed nutrition is increased in availability can metabolism. The feed can optimally be converting to meat.

The percentage determination of carcass and organ in broilers with a basal diet without phytase additives, feed with phytase supplementation from Burkholderia sp. strain HF.7 as a feed additive, and commercial feed for five weeks of maintenance is present in Table 2.
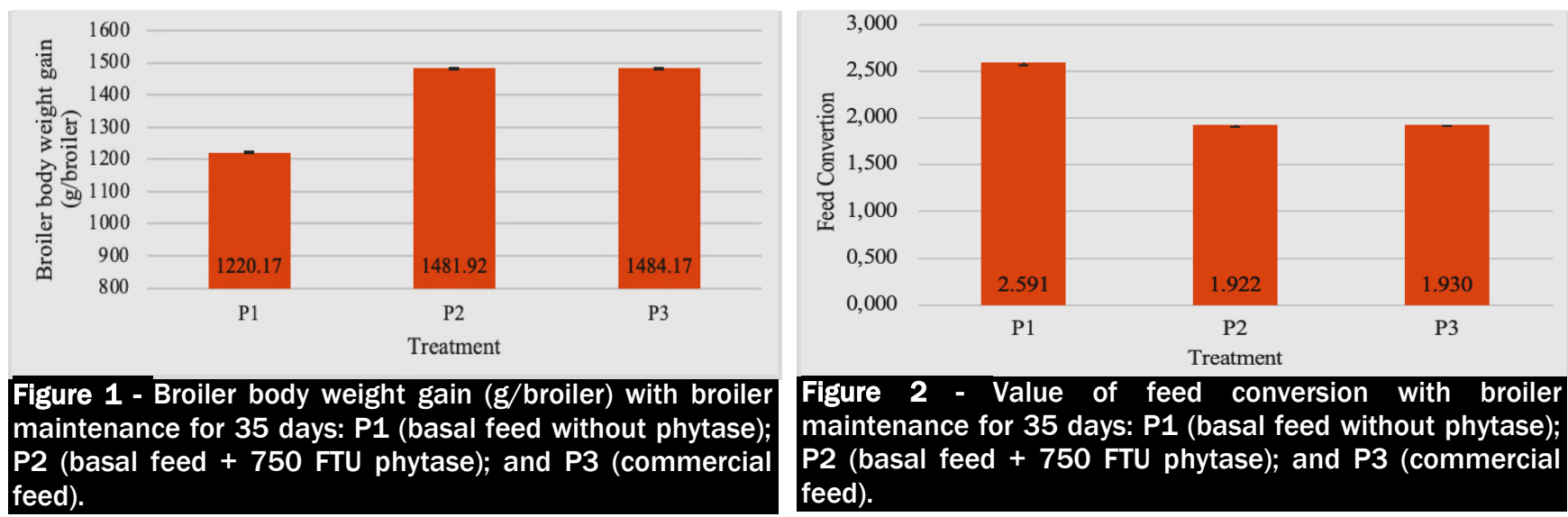

Figure 1 - Broiler body weight gain (g/broiler) with broile maintenance for 35 days: P1 (basal feed without phytase); P2 (basal feed + 750 FTU phytase); and P3 (commercial feed).

Table 2 - Average and standard percentage of broiler's carcass and weight of internal organs.

\begin{tabular}{|c|c|c|c|c|c|}
\hline Percentage & P1 & P2 & P3 & $\begin{array}{l}\text { Standard } \\
\text { Percentage }\end{array}$ & P-Values \\
\hline Carcass weight & $61.2 \pm 0.934$ a & $69.6 \pm 0.842^{b}$ & $69.2 \pm 1.011^{b}$ & $67-72$ & $P<0.05$ \\
\hline Liver (\%) & $2.116 \pm 0.926$ & $2.021 \pm 0.450$ & $1.995 \pm 0.264$ & $1.7-2.8$ & $P>0.05$ \\
\hline Heart (\%) & $0.803 \pm 0.086$ & $0.792 \pm 0.065$ & $0.798 \pm 0.035$ & $0.5-1.4$ & $P>0.05$ \\
\hline Gizzard (\%) & $2.016 \pm 0.752$ & $1.902 \pm 0.784$ & $1.899 \pm 0.881$ & $1.6-2.3$ & $P>0.05$ \\
\hline Lymph (\%) & $1.503 \pm 0.284$ & $1.533 \pm 0.857$ & $1.592 \pm 0.721$ & 1.4-1.9 & $P>0.05$ \\
\hline
\end{tabular}

The difference in broiler growth between treatments P1 and P2 is caused by the occurrence of protein and mineral metabolic disorders which one of the causes is the presence of phytate as in table 1 . Addition of 750 FTU / kg phytase Burkholderia sp. strain HF.7 in feed, significantly increased the growth of broiler experiments $(P<0.01)$ and this fact strengthens the results of some study, that increased growth of broilers that received feed with the addition of phytase showed significant weight gain (Augspurger et al., 2003; Cowieson et al., 2006; Rutherfurd et al., 2012; Fernandes et al., 2019). A different trend occurred between P2 and P3 treatments, in which different broiler body weight gain is not accurate. Bodyweight gain is almost the same as those treatments as in Figure 1 thought to be caused by broilers' ability to be about equal in metabolizing feed the body. Feed nutrition is converted into available nutrients. Digestion and absorption can occur, and the rest that is not absorbed is excreted in the faeces. If digestible energy is converted into metabolic energy that can produce heat and energy for basic life and production activities, the expected growth of broilers will always be average and as expected (Moss et al., 2019). 
The carcass is part of broiler's body after slaughtered and separated from feathers, abdominal fat, internal organs except for lungs, kidneys, legs, head, neck, and blood (Çimrin and Demirel, 2008). Carcass weight percentage was obtained by dividing carcass weight with broiler life weight. The statistical analysis result in table 2 showed that phytase supplementation from Burkholderia sp. strain HF.7 gave a significant effect $(\mathrm{P}<0.05)$ on carcass weight percentage. Overall, 750 FTU phytase from Burkholderia sp. strain HF.7 in each kilogram of feed, increased the carcass weight compared with a basal diet without phytase supplementation. These findings are in agreement with Nourmohammadi et al. (2010) that there is an increase in carcass weight by the addition of Natuphos phytase to roosters and hens fed with low phosphorus levels. some researchers also that phytase in Aspergillus oryzae has a positive effect on carcass weight for poultry fed with low phosphorus levels reported (Angel et al., 2006; Ghosh et al., 2016; Akter et al., 2016; Barzegar et al., 2020). Similarly, other studies with feed containing low levels of phytate phosphate and various commercial phytase levels have a positive effect on carcass weight (Cufadar et al., 2010).

The positive effect on carcass weight by phytase supplementation is due to the absorption of the maximum nutrients in the diet due to the phytase ability to release essential minerals, amino acids, and energy bound from the phytate complex of feed (Dersjant-Li et al., 2015). Nutrients in the feed are released and absorbed, so they can be used for metabolism and help broilers' growth (te Pas et al., 2020). Hence the role of protein has a very substantial in the growth of chicken tissue. Protein absorption ultimately provides faster growth and improves broiler carcass (Kamran et al., 2008; Rezaei et al., 2018). The trend of increasing carcass weights shows in the treatment of feeding using the commercial feed as in table 2. The improvement shows that the quality of basal feed with phytase supplements equals the quality of commercial feed, even without the addition of dicalcium phosphate (DCP), increasing the cost of feed production. The study focus also showed that the percentage of carcasses with P2 and P3 feeds meet the usual broiler carcass percentage standard of about $65-75 \%$ of the weight of live broiler (Aletor et al., 2000).

Analyses of variance indicate that phytase supplementation from Burkholderia sp. strain HF.7 as feed additive does not affect $(P>0.05)$ the weight percentage of organs in the broiler on liver, heart, gizzard or lymph. The average weight percentage of organs in the broiler on each treatment P1, P2, and P3 are list in Table 2. Percentage of liver weight in each treatment ranging from 1.9 to $2.2 \%$ was in the standard range of the liver's healthy weight percentage (1.7-2.8). The percentage of heart weight in each treatment by $0.8 \%$ was in the standard range of healthy heart weight percentage of 0.5 to 1.4. Likewise, the percentage of gizzard and lymph were in the normal range that means the three feed treatments did not disturb the equilibrium percentage of liver, heart, stomach, and lymph of broiler. This data also shows that the addition of phytase from Burkholderia sp. strain HF.7 will not interfere with the broiler organs' physiological function. Thus, it is relatively safe to utilize as a feed additive in the future (Sari and Ginting, 2012; Kokoszyński et al., 2017).

Overall, after the three types of feed in broiler chickens reared for 35 days, feed supplemented with 750 FTU phytase/kg to produce the best feed conversion value and directly proportional to the weight of carcass produced. Supplementation of phytase has proven that the lower feed conversion rate means better feed quality. The high value of feed conversion indicates the need for the amount of feed needed to increase body weight higher and lower feed efficiency. The value of feed conversion is closely related to production costs, primarily feed costs, because the higher the conversion of feed, the cost of feed will increase because the amount of feed consumed to produce body weight in a certain period is higher (McNitt, 1983; Kokoszyński et al., 2017).

\section{CONCLUSION}

The supplementation of Burkholderia sp. strain HF.7 to $750 \mathrm{FTU} / \mathrm{kg}$ of feed may stimulate maximum absorption of nutrients, so that carcass weight is greater and decreases feed conversion ratio. Increased carcass weight and do not affect the percentage of liver, heart, gizzard, and lymph in the broiler.

\section{DECLARATIONS}

\section{Corresponding Author}

E-mail: hafsan.bio@uin-alauddin.ac.id; ORciD: 0000-0001-5821-0164

\section{Acknowledgements}

This study is part of the research obtained from Universitas Islam Negeri Alauddin with internal competitive grant. We thank the Head of Biology Laboratory, Faculty of Science and Technology, UIN Alauddin Makassar and all research teams who have supported this work.

\section{Authors' Contribution}

All authors contributed to research conduction, analyzing and writing, equally.

\section{Conflict of interests}

The authors declare that there is no conflict of interests in this work. 


\section{REFERENCES}

Abdollahi MR, Ravindran V, and Svihus B (2013). Pelleting of broiler diets: An overview with emphasis on pellet quality and nutritional value. Animal Feed Science and Technology, 179(1-4): 1-23. Article link I https://doi.org/10.1016/j.anifeedsci.2012.10.011

Akter M, Graham H and lji PA (2016). Response of broiler chickens to different levels of calcium, non-phytate phosphorus and phytase. British Poultry Science, 57(6):799-809. Article link | https://doi.org/10.1080/00071668.2016.1216943

Aletor VA, Hamid I, Nieß E, and Pfeffer E (2000). Low-protein amino acid-supplemented diets in broiler chickens: effects on performance, carcass characteristics, whole-body composition and efficiencies of nutrient utilization. Journal of the Science of Food and Agriculture, 80(5): 547554. Article link I https://doi.org/10.1002/(SICI)1097-0010(200004)80:5\%3C547::AID-JSFA531\%3E3.0.C0;2-C

Angel R, Saylor WW, Mitchell AD, Powers W and Applegate TJ (2006). Effect of dietary phosphorus, phytase, and 25-hydroxycholecalciferol on broiler chicken bone mineralization, litter phosphorus, and processing yields. Poultry Science, 85(7): 1200-1211. Article link I https://doi.org/10.1093/ps/85.7.1200

Augspurger NR, Webel DM, Lei XG and Baker DH (2003). Efficacy of an E. coli phytase expressed in yeast for releasing phytate-bound phosphorus in young chicks and pigs. Journal of Animal Science, 81(2): 474-483. Article link I https://doi.org/10.2527/2003.812474x

Aureli R, Faruk MU, Cechova I, Pedersen PB, Elvig-Joer SG, Fru F and Broz J (2011). The efficacy of a novel microbial 6-phytase expressed in aspergillus oryzae on the performance and phosphorus utilization in broiler chickens. International Journal of Poultry Science, 10(2): 160168. Article link I https://doi.org/10.3923/ijps.2011.160.168

Barzegar S, Wu SB, Choct M and Swick RA (2020). Factors affecting energy metabolism and evaluating net energy of poultry feed. Poultry Science, 99(1): 487-498. Article link I https://doi.org/10.3382/ps/pez554

Benton T, and Bailey R (2019). The paradox of productivity: Agricultural productivity promotes food system inefficiency. Global Sustainability, 2: E6. Article link I doi: https://doi.org/10.1017/sus.2019.3

Bonham JG, Bosch DJ and Pease JW (2006). Cost-Effectiveness of nutrient management and buffers: comparisons of two spatial scenarios. Journal of Agricultural and Applied Economics, 38(1): 17-32. Article link I https://doi.org/10.1017/S1074070800022045

Çimrin T and Demirel M (2008). Effect of dietary phytase and some antioxidants on the fattening performance of broilers. Journal of Applied Animal Research, 34(1): 55-59. Article link I https://doi.org/10.1080/09712119.2008.9706940

Cowieson AJ, Acamovic T and Bedford MR (2004). The effects of phytase and phytic acid on the loss of endogenous amino acids and minerals from broiler chickens. British Poultry Science, 45(1): 101-108. Article link I https://doi.org/10.1080/00071660410001668923

Cowieson AJ, Acamovic T and Bedford MR (2006). Phytic Acid and phytase: implications for protein utilization by poultry. Poultry Science, 85(5): 878-885. Article link I https://doi.org/10.1093/ps/85.5.878

Cufadar Y, Olgun O, Bahtiyarca Y and Yildiz AÖ (2010). Effects of dietary energy content on the breeder chukar partridge's performance and laying traits (Alectoris chukar) housed in battery cages or litter floor pens. Revue de Medecine Veterinaire, 161(3): 99-103. Article link I https://www.revmedvet.com/2010/RMV161 99 103.pdf

Daghir NJ (2009). Nutritional strategies to reduce heat stress in broilers and broiler breeders. Lohmann Information, 44(1), 6-15. Article link I https://www.lohmann-information.com/content/I_i_44_artikel2.pdf

Dersjant-Li Y, Awati A, Schulze H, and Partridge G (2015). Phytase in non-ruminant animal nutrition: a critical review on phytase activities in the gastrointestinal tract and influencing factors. Journal of the Science of Food and Agriculture,95(5): 878-896. Article link I https://doi.org/10.1002/jsfa.6998

dos Santos TT, Srinongkote S, Bedford MR and Walk CL (2013). Effect of high phytase inclusion rates on performance of broilers fed diets not severely limited in available phosphorus. Asian-Australasian Journal of Animal Sciences, 26(2): 227-232. Article link I https://doi.org/10.5713/ajas.2012.12445

Fernandes JIM, Horn D, Ronconi EJ, Buzim R, Lima FK and Pazdiora DA (2019). Effects of Phytase Superdosing on Digestibility and Bone Integrity of Broilers. Journal of Applied Poultry Research, 28(2): 390-398. Article link I https://doi.org/10.3382/japr/pfz001

Ghosh A, Mandal GP, Roy A and Patra AK (2016). Effects of supplementation of manganese with or without phytase on growth performance, carcass traits, muscle and tibia composition, and immunity in broiler chickens. Livestock Science, 191: 80-85. Article link I https://www.sciencedirect.com/science/article/abs/pii/S1871141316301652

Hafsan H, Nurhikmah N, Harviyanti Y, Sukmawati E, Rasdianah I, Muthiadin C, Agustina L, Natsir A and Ahmad A (2018). The potential of endophyte bacteria isolated from Zea mays L. as Phytase Producers. Journal of Pure and Applied Microbiology, 12(3): 1277-1280. Article link I https://doi.org/10.22207/JPAM.12.3.29

Hafsan, Sukmawaty E, Masri M, Ahmad A, Agustina L and Natsir A (2018). Phytase Activity of four endophytes bacteria from zea mays L. CABES2018 April 17-18, 2018 Kyoto (Japan): 56-60. Article link I https://doi.org/10.17758/IICBE1.C0418153

Hirvonen J, Liljavirta J, Markku T, Saarinen, Markus J, Lehtinen, Ahonen I and Nurminen P (2019). Effect of phytase on in vitro hydrolysis of phytate and the formation of myo-inositol phosphate esters in various feed materials. Journal of Agricultural and Food Chemistry, 67 (41): 11396-11402. Article link I https://doi.org/10.1021/acs.jafc.9b03919

Humer E, Schwarz C and Schedle K (2015). Phytate in pig and poultry nutrition. Journal of Animal Physiology and Animal Nutrition, 99(4): 605625. Article link I https://doi.org/10.1111/jpn.12258

McNitt J (1983). Livestock Husbandry Techniques. HarperCollins Distribution Services.

Kamran Z, Sarwar M, Nisa M, Nadeem MA, Mahmood S, Babar ME and Ahmed S (2008). Effect of low-protein diets having constant energy-toprotein ratio on performance and carcass characteristics of broiler chickens from one to thirty-five days of age. Poultry Science, 87(3): 468 474. Article link I https://doi.org/10.3382/ps.2007-00180

Kokoszyński D, Bernacki Z, Saleh M, Stęczny K and Binkowska M (2017). Body Conformation and Internal Organs Characteristics of Different Commercial Broiler Lines. Revista Brasileira de Ciência Avícola, 19(1): 47-52. Article link I https://doi.org/10.1590/1806-9061-20160262

Krishnasamy V, Otte J and Silbergeld E (2015). Antimicrobial use in Chinese swine and broiler poultry production. Antimicrobial Resistance and Infection Control, 4(1): 17. Article link I https://doi.org/10.1186/s13756-015-0050-y

Liu SY, Cadogan DJ, Péron A, Truong HH and Selle PH (2014). Effects of phytase supplementation on growth performance, nutrient utilization and digestive dynamics of starch and protein in broiler chickens offered maize, sorghum and wheat-based diets. Animal Feed Science and Technology, 197: 164-175. Article link I https://doi.org/10.1016/j.anifeedsci.2014.08.005

Maas RM, Verdegem MCJ, Debnath S, Marchal L and Schrama JW (2021). Effect of enzymes (phytase and xylanase), probiotics (B. amyloliquefaciens) and their combination on growth performance and nutrient utilization in Nile tilapia. Aquaculture, 533: 736226 . Article link I https://doi.org/10.1016/j.aquaculture.2020.736226 
Manning L, Baines RN and Chadd SA (2006). Food safety management in broiler meat production. British Food Journal, 108(8): 605-621. Article link I https://doi.org/https://doi.org/10.1108/00070700610681987

Moss AF, Chrystal PV, McQuade LR, Cadogan DJ, Yun Liu S and Selle PH (2019). The influence of exogenous phytase on the post-enteral availability of amino acids in broiler chickens offered wheat-based diets. Animal Feed Science and Technology, 258, 114300. Article link I https://doi.org/10.1016/j.anifeedsci.2019.114300

Nourmohammadi R, Hosseini SM, Farhangfar H (2010). Influence of citric acid and microbial phytase on growth performance and carcass characteristics of broiler chickens. American Journal of Animal and Veterinary Sciences. 5(4):282-8. Article link I https://doi.org/10.3844/ajavsp.2010.282.288

Rezaei M, Yngvesson J, Gunnarsson S, Jönsson L and Wallenbeck A (2018). Feed efficiency, growth performance, and carcass characteristics of a fast- and a slower-growing broiler hybrid fed low- or high-protein organic diets. Organic Agriculture, 8(2):121-8. Article link I https://doi.org/10.1007/s13165-017-0178-6

Rutherfurd SM, Chung TK, Thomas DV, Zou ML and Moughan PJ (2012). Effect of a novel phytase on growth performance, apparent metabolizable energy, and the availability of minerals and amino acids in a low-phosphorus corn-soybean meal diet for broilers. Poultry Science, 91(5): 1118-1127. Article link I https://doi.org/10.3382/ps.2011-01702

Santoso U (2012). Pengaruh pembatasan Pakan pada Awal Umur yang Berbeda terhadap Performa dan Profil Lipid pada Broiler Umur Empat Dua Hari. Jurnal Sain Peternakan Indonesia, 7(2): 51-56. Article link I https://doi.org/10.31186/jspi.id.7.2.51-56

Sari ML and Ginting FGN (2012). Pengaruh Penambahan Enzim Fitase Pada Ransum terhadap Berat Relatif Organ Pencernaan Ayam Broiler. Jurnal Agripet, 12(2): 37-41. Article link I https://doi.org/10.17969/agripet.v12i2.201

Savita PD, Suvarna VC, Yallappa M, Nivetha N (2010). Phytate solubilizing microorganisms and enzyme phytase to combat nutritional problems in cereal-based foods. Journal of Bacteriology and Mycology. 2017;4: $00093 . \quad$ Article link I https://doi.org/10.15406/jbmoa.2017.04.00093

Selle PH, Ravindran V, Caldwell A and Bryden WL (2000). Phytate and phytase: consequences for protein utilization. Nutrition Research Reviews, 13(2): 255-278. Article link I https://doi.org/10.1079/095442200108729098

Shirley RB and Edwards HM (2003). Graded levels of phytase past industry standards improves broiler performance. Poultry Science, 82(4): 671680. Article link I https://doi.org/10.1093/ps/82.4.671

Tallentire CW, Leinonen I, and Kyriazakis I (2016) Breeding for efficiency in the broiler chicken: A review. Agronomy for Sustainable Development, 36(4):1-6. Article link I doi: https://doi.org/10.1007/s13593-016-0398-2

te Pas MFW, Borg R, Buddiger NJH (2020). Regulating appetite in broilers for improving body and muscle development - A review. Journal of Animal Physiology and Animal Nutrition, 104(6): 1819- 1834. Article link I https://doi.org/10.1111/ipn.13407

Walker P, Rhubart-Berg P, McKenzie S, Kelling K and Lawrence RS (2005). Public health implications of meat production and consumption. Public Health Nutrition, 8(4): 348-356. Article link I https://doi.org/https://doi.org/10.1079/PHN2005727

Wenk C (2000). Recent advances in animal feed additives such as metabolic modifiers, antimicrobial agents, probiotics, enzymes and highly available minerals - Review. Asian-Australasian Journal of Animal Sciences, 13(1): 86-95. Article link I https://doi.org/https://doi.org/10.5713/ajas.2000.86 